\title{
in the northern
territory intervention what is saved or rescued and at what cost? \\ IRENE WATSON
}

The foundation of the Australian colonial project lies within an 'originary violence', in which the state retains a vested interest in maintaining the founding order of things. Inequalities and iniquities are maintained for the purpose of sustaining the life and continuity of the state. ${ }^{1}$ The Australian state, founder of a violent (dis)order is called upon by the international community to conform and uphold 'human rights', but what does this call to conformity require, particularly when the call comes from states which are also founded upon colonial violence? It is my argument that very little is required beyond the masquerade that 'equality' for Aboriginal peoples is an on-going project of the state. So for what purpose does the masquerade continue? The masquerade of equality is essential to the notion of foundation and state legitimacy even though inside the colonial state 'equality' is never a possibility. The bare minimum notion of 'rights' is allowed, in what Ranciere suggests is a space that is diminishing daily, until 'rights' appear empty and devoid of use. ${ }^{2}$ Ranciere compares the idea of rights of the oppressed to the charitable giving of second-hand clothes to the poor, or the sending of aid abroad to 'deprived peoples'.

Australia does not have to look overseas to extend the 'charity' of human rights; the colonisation of Aboriginal people's lives and territories has been an ongoing project in the maintenance of inequality-inequality between Aboriginal life and a privileged colonial settler society. The standing inequality between the Aboriginal and settler societies provides fertile ground for human rights interventions. In June 2007 the Howard Coalition government announced it would lead an intervention into Aboriginal communities in the Northern Territory (NT) as a response to the findings of the Little Children are Sacred report, which reported on high levels of community violence against Aboriginal children and women. ${ }^{3}$ 
Without negotiating with Aboriginal communities the Australian federal government announced its own strategy to intervene in the 'crisis' within Northern Territory Aboriginal communities, and enacted the Northern Territory National Emergency Response Bill (Cth) 2007. ${ }^{4}$

Soon after the announcement the intervention commenced and was led, like those in Iraq and Afghanistan, by the Australian military. According to the Australian government the intervention will save and transform the lives of Aboriginal peoples living on Aboriginal lands that have been recognised since 1975 as such under the NT Aboriginal Land Rights Act (Cth). The Howard federal government argued that its emergency intervention was a 'just' and 'humanitarian' act, while the incoming and now current federal Labor government fully supports its opponent's intervention laws. But are they just? Derrida argues that the mere application of a rule 'without a spirit of justice' might be protected to stand as 'law' but it would not be 'just'. ${ }^{5}$ In this instance the Australian government stands protected by law, a law that continues to play out and re-enact its own unjust foundational position, one which took root in innumerable acts of colonial violence and continues today as violent re-enactments. But these violent re-enactments are not seen as violence. This is because the violence is normalised. The intervention was read by some as a contemporary invasion of Aboriginal lands but the Australian public and its political system read it as a humanitarian intervention, as a lawful process of the Australian state. ${ }^{6}$

I understand the contemporary colonial project as one which has continued unabated from the time of the landing and invasion by the British in 1788, and which created a state founded on colonial or 'originary' violence. ${ }^{7}$ It is from this foundation that the Australian state retains a vested interest in keeping the violence going, and the inequalities and iniquities that are maintained against Aboriginal peoples for the purpose of maintaining the life and continuity of the state. A question the Australian state is yet to resolve is its own illegitimate foundation and transformation into an edifice deemed lawful. Within this unanswered questionable structure the Australian state parades as one which has obliterated the 'founding violence' of its 'illegitimate' origins, and 'repressed them into a timeless past', ${ }^{8}$ while the survivors of this founding violence ask the state: by what lawful process do you come to occupy our lands?

The Commonwealth emergency response to Aboriginal violence is focused only on the Northern Territory-it is only the NT that has a federal Aboriginal land rights regimebut the NT is also earmarked for the opening of a number of new uranium mines. Coincidentally, a new railway line built by a consortium which included a subsidiary of Halliburton is routed from Adelaide to Darwin and crosses Aboriginal lands in the NT to provide easy access to shipping routes. ${ }^{9}$ Clearly none of these facts have been cited as being relevant or having any connection to the new emergency laws - the media and public focus is solely upon child sexual abuse and the possibility of its prevention and protection-but 
they are certainly coincidental. Wendy Brown writing on humanitarian intervention suggests the state's intervention in crisis events is probably more about a 'particular form of political power carrying a particular image of justice'. ${ }^{10}$ In the Australian context that image of justice is one which enables the violent foundations of colonialism to continue to hold territory and transform the life of Aboriginal peoples. It is a violent act which masquerades as being beneficial to impoverished Aboriginal communities across the NT, but one that once again boils down to the legitimising of the right to invasion of Aboriginal lands and lives. ${ }^{11}$

Across colonial history, Australian law and society held and continues to hold the power to construct and identify that which is Aboriginal law and culture, a position which has resulted in translations and constructions of Aboriginal law and culture as being inherently violent against women and children. This position has allowed an opening for crusaders or 'white men to come to the rescue of brown women from brown men', as Spivak suggested when commenting on the dynamics of a colonial India and the 'rescue' by white men of Indian women from the 'barbaric practice' of widow sacrifice. ${ }^{12}$ The position of crusader is held up as the 'proper' solution to violence. ${ }^{13}$ But in this universalised order whose concept of human rights and equality applies? And will the 'originary violence' be transformed into a law-full act of humanitarian intervention which obliterates its own past?

The federal government's concept of human rights was applied to provide 'protection' from violence in Aboriginal communities across the NT, but it remains important to examine what is being protected and the position and power held by 'contemporary Aboriginal Protectors'. It is my argument that the current emergency response laws are the contemporary representation of earlier colonial laws and protectionist policies of the Aborigines Acts, and that these (now repealed) laws were in their time of operation also characterised as being of benefit to Aboriginal peoples. ${ }^{14}$

Across time, from the moment of the original violence of foundation to this time now, the same question can be asked: what was it/is it that Aboriginal people are being protected from? In the past the black frontier experience was one of physical violence: white settlers effected massacres, murders and kidnappings, and as a result of their pressure, starvation and disease were also rife. Often official protection was ineffective. On the white side of the frontier however, it was and still is strongly contested that any frontier violence had occurred at all. ${ }^{15}$ It is now claimed that under the recently imposed Commonwealth intervention laws Aboriginal individuals, particularly women and children, would be protected from the violence of Aboriginal male members of their communities. Women and children would be protected from a 'failed Indigenous experiment' in respect of which the Howard government:

would no longer stomach a policy regime whose many failings resulted in endemic poverty, alienation and disadvantage, and sickening levels of abuse of Aboriginal women and children. 
They rolled out a policy revolution. With the dis-establishment of ATSIC and the removal of elected commissioners whose public reputations were in tatters following allegations of rape, corruption and incompetence, a new order swept in. ${ }^{16}$

Langton's support for the new order fails to acknowledge the Howard government's complicity and power to determine otherwise; that is, during the previous decade the Howard government held power to intervene in Aboriginal community endemic poverty, alienation, disadvantage and community violence, but chose instead to do nothing, chose to sit back and observe like the vulture state it was and to swoop in upon communities at the point of implosion. So why did the state fail to intervene or act earlier? The implosion of communities was well represented by the Australian media but in their representation they failed to provide a critical commentary of the Howard government's failure to engage with Aboriginal community development. ${ }^{17}$

The white settler frontiersman of the past has been transformed by the NT intervention into the crusader of the present, rescuing Aboriginal women from Aboriginal men. The question to be asked is: what has happened in the intervening 200 years and why does the violence continue to occur intergenerationally in this changed and inverted context?

In coming to these questions it is important to distinguish the nature and character of violence in Aboriginal communities. Early colonial frontier violence was pitched against first peoples' laws and cultures, a foundational violence which established a colonial sovereignty. However, contemporary violence is more complex; it is characterised by violence of Aboriginal against Aboriginal, but the violence of the state also retains its original character against Aboriginal peoples' laws and cultures. It is a colonial violence which re-enacts itself to support its claim to legitimate foundation, and the Howard government emergency measures are such a re-enactment.

I don't think we can fully comprehend these recent developments without reflecting on history. In the past the colonial state cast the net of what I have called in previous works an illusion of protection or the masquerade of recognition of the humanness of Aboriginal peoples. ${ }^{18}$ But under the protectionist policies of the Aborigines Acts our lives were totally controlled. Our old people were forced to live on reserve lands and were only allowed to leave the reserve once they obtained the permission of the Aboriginal Protector, or held an exemption certificate exempting them from being identified as an Aborigine under the Aborigines Acts. ${ }^{19}$

So who am I/we today in this new so-called 'post-colonial landscape'? ${ }^{20}$ This question is particularly relevant to situations of native title claims where Aboriginal culture and identity is interrogated for authenticity, but apart from this it is also interrogated in another context. In the past our ability to truly live as Aboriginal peoples was subjugated entirely by 
colonial policies, but during the 1970s there was a symbolic shift to 'recognition' of Aboriginal lands, laws and cultures. However, recently we have been made aware most explicitly by the Howard government and now also the current Rudd government that these shifts in the 1970s were never based on firm ground but were vulnerable 'rights recognition' secured only by the 'human rights movement' of the times. So what are these times and how far if at all have we shifted from the original founding colonial intentions?

Prior to the commencement of the NT intervention Aboriginal culture and collective forms of land ownership were deemed subversive to 'proper' forms of property ownership. In a speech to the Commonwealth Parliament Senator Mal Brough spoke in support of amendments to the Northern Territory Land Rights Act (Cth) 1975, arguing that private property rights would provide safer and more progressive developments for Aboriginal communities. ${ }^{21} \mathrm{At}$ the same time, negating the possibility for judicial consideration of Aboriginal cultural background was also considered by the Commonwealth as an advancement of universal human rights standards. ${ }^{22}$ The build-up to the NT intervention secured the passage of Commonwealth laws, marking a retreat from the 'recognition' of Aboriginal land rights, laws and culture.

The original colonial intentions were to establish colonies that were to become transformed into the Australian state. At the time of its foundation we were the non-native colonisers' natives, but we were ourselves Tanganekald ${ }^{23}$ or other peoples, by our own names. Our identity and voices were unknown to the colonisers and unheard, but they have survived the attempted genocide. Today our voices are still talking while the colonial project remains entrenched and questions concerning identity politics, and the 'authentic native', are constructed and answered by those who have power to determine the legal and political categories of Aboriginal and non-Aboriginal. The categories of Aboriginal and non-Aboriginal were imposed by the colonial project and in this process of constructing Aboriginal and nonAboriginal identities, the colonisers excluded themselves from having an Indigenous past. ${ }^{24}$ I see this process of negating an Aboriginal identity as being tied to the idea of progress or the movement towards a 'vanishing future', away from an Aboriginal being, and relationships or connections to country.

While the colonial project from the outset denied and extinguished Aboriginality it seems contradictory that the commodification of Aboriginal culture brings an increased demand for authenticity—of Aboriginal art, and other tangible and intangible 'products'. Commodification occurs even while the survival of the 'authentic native' was and is threatened by colonialism, and while at the same time the state enables the space of annihilation, a space that at the same time demands the 'authentic native'. Who we are is often navigated from a violent space within which Aboriginality is measured for its degree of authenticity, and where those who do the measuring are ignorant or deniers of the history of colonialism. So when the struggle and desire for an Aboriginal life is depicted by the state as being no more than 
an invention or fabrication of culture and law, as was found in the Hindmarsh Island Bridge Royal Commission (South Australia), ${ }^{25}$ we are reduced of our Aboriginality. The Hindmarsh Island Bridge Royal Commission inquired into the authenticity of Aboriginal women's law business and concluded that Aboriginal women had invented law business, and found that the practice had never been a part of Aboriginal cultures in the southern and southeastern regions of South Australia. The commission was established to determine the truth or otherwise behind the claim that the building of a highway bridge from mainland Goolwa to Hindmarsh Island would destroy a significant Aboriginal women's site. Royal Commissioner Iris Stevens concluded that Aboriginal women's law was a fabrication or reinvention of traditional Aboriginal culture and law, for the purpose of preventing the building of the bridge. Since then the bridge has been built and a number of Aboriginal women continue to contest and resist the legitimacy of the decision which enabled the damage of an important Aboriginal site.

Aboriginal culture and identity is more likely to be supported when it is not challenging development projects and when culture performs as a commodity. However, when Aboriginality challenges the political agendas of the state, it is most likely to be attacked or demeaned as it was by Iris Stevens when she determined women's business was a fabrication and a reinvention of the past. Here the state determined the process of cultural translation, and the evidence relied upon was taken from white male experts, while the evidence of women's business was not presented to the commission because the proponents of Aboriginal women's business did not acknowledge the jurisdiction of the Royal Commission. How can anyone consider the possibility of cultural translation when the source of the translation has no status or even presence? When the information relied upon is that of the 'white expert' what is being translated? It is a compilation of their record of events; the Aboriginal record has no speaking voice. The outcome of the commission was to conclude an invention of tradition, a conclusion that resulted in the damage of a site of significance to Aboriginal women's law and cultural business. The discourse of progress framed and determined the processes of translation and the conclusions reached by the commission.

Zizek, in consideration of Scottish kilts, their origins and history writes, 'in the very act of returning to tradition, they are inventing it'. ${ }^{26}$ He was referring to a specific history of place and people, a subject which cannot be conveyed to every known territory. However, the concept of invention of tradition is imposed broadly and occurred during the Hindmarsh Island Bridge Royal Commission. It was applied to a place where Aboriginal peoples are in struggle for the land and a space to re-establish a life beyond that of subjugated natives. The possibility for decolonisation or engagement with Aboriginal world views on law and culture was rendered a fabrication by Iris Stevens, of the same species as Zizek's act of invention. Does a space in which there might be Aboriginality beyond a fabricated invention or a commodified 
Aboriginal being exist? The cynic in me would say no; the resisting-survivor would say it is the challenge.

In a critique of the 'tolerance' of liberal multiculturalism, Zizek reasons most unreasonably: 'an experience of Other deprived of its Otherness (the idealized Other who dances fascinating dances and has an ecologically sound holistic approach to reality, while features like wife-beating remain out of sight)? ${ }^{27}$ Here Zizek renders the 'other' as 'real' without being so, for the real 'reality show' is not Aboriginal relationships to country but the out-of-sight wife beating. This is real. But what of the reality of relationships to country; here they are demeaned as invention of tradition while the real is wife beating. What is real and where is the reality space of colonialism as a determined player in the construction of the other's identity and responses to violence and the intergenerational traumas of colonialism? What has been stripped here is an Aboriginal context of life or an Aboriginal reality and not one as suggested by Zizek that is divested of substance resisting that which is real.

Colonial policies of protection were initially applied with the expectation that there would be a decline and eventual extinguishment of the 'native'. They would all die. When native populations, however, successfully resisted extinguishment, protectionist policies were replaced by policies of assimilation which assumed not that the natives would all die, but that cultural annihilation would occur. These policies more or less continue in various guises, but the recent Australian government intervention into the NT works differently to colonial policies of the past. Aboriginal reserve lands which were set aside under the Aborigines Acts of the past for the purpose of sustaining protectionist policies of exclusion later formed the land base for the Northern Territory Land Rights Act (Cth), 1975. These lands have now been targeted for large-scale development and the bringing of both country and peoples into modernity. The 'emergency intervention' is supported by a package of Commonwealth laws which have been referred to by both major political parties as a necessary human rights intervention to relieve the crisis in Northern Territory Aboriginal communities. ${ }^{28}$

We might ask: was the sole purpose of the Commonwealth intervention to save and transform lives and in particular the lives of Aboriginal children? The intervention is being led by the Australian military and this raises the question whether this hard-line offensive precludes or negates other ways of dealing with violence in Aboriginal communities. For example, from early colonial times Aboriginal peoples have attempted to negotiate with the colonial powers on Aboriginal strategies that could work towards alleviating suffering in communities across Australia. For more than thirty years Aboriginal strategies such as alternative justice models, and rehabilitation and healing centres modelled on Aboriginal cultural knowledge have largely been ignored or if they have been supported it has been in a tokenistic manner.

In considering the military intervention into Aboriginal communities, I am interested in the question that Wendy Brown raises regarding humanitarian intervention: 'what kinds of 
subjects and political (or antipolitical) cultures do they bring into being as they do so, what kinds do they transform or erode, and what kinds do they aver?' ${ }^{29}$ It is a question which could also be applied to the early colonisation of Australia, and to this scenario we have an answer: what was brought into being was large scale dispossession of peoples from land, culture and law, peoples left without space to survive inside a colonial body that continually works to subjugate the 'native' to the trajectories of progress. Will Aboriginal communities be able to hold onto their land, or will they be removed? We have seen this history performed in the past. So what kinds of Aboriginal identities will form out of this most recent 'humanitarian intervention'? 30

As the intervention laws begin to peel back the provisions of the Northern Territory Land Rights Act (Cth) 1975 we are yet to see the extent to which the Rudd Labor government will follow in line with that of its predecessor, the Howard government, and its original intention. At the time of writing there is little to distinguish Rudd's policy from Howard's. It is, however, difficult to extrapolate all the intentions behind humanitarian intervention, because interventions by their nature are masked by the illusion of missionary goodwill, masking which is all the more powerful because of the real hardship and poverty of the peoples who are subjects of the intervention. What is to be saved or transformed by the NT intervention, or what is likely to be achieved? Is the intervention really about fixing the Aboriginal position of endemic poverty and violence or is it a land grab? Any answers to the above must critically consider that if intentions were sincere, why has the state taken so long to act, and why now? We know that the Australian government has spent the past decade de-funding and closing down Aboriginal initiatives and programs that were improving living conditions in Aboriginal communities across Australia, and might have gone further if they had been allowed to continue.

The Broad Inquiry Into the Protection of Aboriginal Children From Sexual Abuse report recommended collaboration of state and federal governments in consultation with Aboriginal communities to address the issue of child abuse as a matter of national emergency. But collaboration and consultation with Aboriginal communities and the Northern Territory was not considered by the Howard federal government. It has been suggested (and I am in agreement) that the Howard government's intervention had less to do with addressing the question of child abuse and more to do with the government gaining greater access to Aboriginal lands, as well as weakening the position of Aboriginal law and culture. ${ }^{31}$ The intervention was planned and effected but to date it has not been proven that there is any link between the intervention measures and child abuse.

As stated above, the Rudd government's response supports the intervention and appears to share the same goal as the previous government: to gain greater access to and control over Aboriginal lands. The emergency intervention laws, while covering a broad area, include 
three measures that have been identified as having the most potential to negatively impact upon the continuity of Aboriginal relationships to land. The first involves relaxing the Aboriginal permit system which allowed Aboriginal people to exclude or remove persons from 'common areas' and access roads into their communities and lands. ${ }^{32}$ While the Coalition government and the supporters of this provision argued that greater access for the media and other members of the public would reduce the remoteness and increase public scrutiny of these communities, on the other side many Aboriginal peoples have argued that easier public access would open the lands to an increase in drug and grog runners into communities where the drinking of alcohol is restricted or prohibited. Secondly, the compulsory acquisition of Aboriginal townships for five years will provide for the compulsory transfer to government control of approximately seventy Aboriginal townships and settlements in the Northern Territory. Over these lands five-year leases will be compulsorily taken up by the Commonwealth using powers under Section 51 (xxxi) of the Constitution. The Howard government stated that compulsory acquisition of townships was necessary to allow unfettered access to Aboriginal townships; however, both state and federal bureaucrats already had access to meet and negotiate with communities on a range of issues. Compulsory acquisition would not provide any greater benefit to the Aboriginal communities in the critical areas of health, housing and education. ${ }^{33}$ Thirdly, the intervention laws disallow the consideration of customary law or the cultural background of an offender in sentencing or bail proceedings. ${ }^{34}$ Critics of the intervention laws have argued that these amendments are most likely to result in higher incarceration rates and also undermine the work of Aboriginal courts and their efforts at community involvement in a dialogue on culture and the increased involvement with community people and elders. In my current research, which maps the sentencing remarks of justices in the Northern Territory, I have found no evidence of a more lenient sentence of an Aboriginal offender where the courts have considered the 'cultural background' of the defendant but the government played upon populist sentiments that this in fact was happening. ${ }^{35}$ The emergency response laws are now being challenged for contravening Australia's obligations under international law and the Convention on the Elimination of All Forms of Racial Discrimination. ${ }^{36}$

Initially, the National Emergency Response laws found their legitimacy in the findings of the Little Children are Sacred report. The report was the result of an eight-month inquiry which held consultations with forty-five communities: 260 meetings, sixty written submissions, and ninety-seven recommendations, most of which were ignored by the federal government. Instead, the government headlined the report's finding that child sexual abuse was endemic in Aboriginal communities, and decided upon fast-tracking and implementing the emergency response with all its powers to compulsorily acquire land. The Little Children are Sacred report's recommendation that it was necessary to address social, economic, 
violence and substance-abuse issues in close consultation with communities was ignored. Instead, the Australian military entered and targeted Aboriginal communities without prior consultation or their consent.

There have been a number of Aboriginal responses to the intervention-mine, like many, is an outsider's view. I am not an Aboriginal person living in any of the communities which were the subjects of the Little Children are Sacred report and now targeted by the emergency response. From experience and long-term connections and relationships with friends living in some of the targeted communities, however, I know that the physical and economic violence suffered by some members of those communities is critical and it has been for a long time. I was the director of the Aboriginal Legal Rights Movement in Adelaide in 1988, and I was contacted by members of a remote South Australian community and asked to assist in their negotiations for a greater police presence within their community. For me, it was a difficult position to be placed in. In my life, led in more 'settled' areas of South Australia, police practices had deliberately targeted Aboriginal men, women and children as part of a strategy of maintaining an Aboriginal-free space for white people. We were the enemy for no reason other than our Aboriginality. So to consider the need to call upon the police to aid and protect members of Aboriginal communities was a very different proposition to the one I had lived with and known. The 1988 call for a greater police presence was to assist with the alarmingly high levels of substance-abuse related violence. That call has been consistent for some twenty or more years, not only from communities within the NT but from across Australia. But the call for increased services was not only for improved policing, it was also for services that would improve the overall well-being of communities in health, education, and housing.

But while there is widespread criticism of the emergency response, a number of communities have expressed support. I would argue this support is an indication of how critical the situation has become in those communities rather than being an expression of support for the manner in which the federal government has acted. It's hard to see enthusiasm for sending in the military and amending the Northern Territory Land Rights Act (Cth) 1975 so as to transfer control of Aboriginal townships to the Commonwealth government.

I have recently written about the long Australian media campaign waged against Aboriginal culture and law prior to the announcement of the emergency response, and I have argued the many acts of demonisation by the media have enabled the space for the current emergency response to enter and occupy with very little opposition. ${ }^{37}$ In post-intervention media debate the focus shifted to ideological differences within Aboriginal communities concerning the emergency response. The media facilitated a public slanging match between two Aboriginal women, both members of the NT Labor government, who held opposing views on the response. Alison Anderson, in line with Kevin Rudd's national Labor policy, publicly supported 
the emergency response and condemned Marion Scrymagour's rigorous opposition to it for being out of touch with 'grass roots' community concerns. ${ }^{38}$ Scrymagour had argued that there appeared to be no rational linkage between the need to rescue women and children from sexual abuse and the compulsory acquisition of their land. The emergency response has taken on the mantle of being the bringer of 'human rights' and to speak against it for whatever reason is to be against the advancement of the human rights of Aboriginal communities and an advocate for violent black men. ${ }^{39}$ At least this is how both major Australian political parties and their investors, both Aboriginal and non-Aboriginal, in the lead-up to the federal election allowed the event to be characterised by the Australian media. I, among others, would characterise the emergency response differently. ${ }^{40}$

As I have flagged earlier in this article the emergency response is a continuing play for legitimacy, and the act of legitimacy is the rescue of Aboriginal women and children from the violence of Aboriginal men. In the protection racket of shielding and protecting subjects from certain abuses they also become subjects in the tactics of their disempowerment. In the story of the NT intervention that disempowerment comes in the form of weakened land tenure and the loss of opportunity to build communities from an Aboriginal centre and knowledge base. ${ }^{41}$ In the rescue mission Aboriginal townships will be taken over by the federal government for the purpose of providing access to health, housing and education, but the provision of essential services will be at the cost of Aboriginal autonomy over township areas. ${ }^{42}$ Instead of shifting the colonial imbalance towards a decolonised space the state further entrenches the colonial project by reviving protectionist policies, this time under the rubric of human rights. We are returned to the stereotype of the barbaric violent bashing native, one that is in need of protection from ones 'own kind'. Here it is not my intention to deny the experiences of chronic poverty, violence, poor health, housing shortages and poor education outcomes existing in the life of many Aboriginal peoples, or the need for action to remedy this critical condition, but to critically evaluate the intervention processes. Wendy Brown makes the point that 'there is no such thing as mere reduction of suffering or protection from abuse-the nature of the reduction or protection is itself productive of political subjects and political possibilities'. ${ }^{43}$ The political subjects which are reproduced are Aboriginal peoples who continue to be subjugated by the colonial body state, having no possibility of shifting to or opening up a decolonised space. The intervention has had the effect of foreclosing any possibility of that because the construction of the 'violent native' provides the legitimacy to that foreclosure.

What are the possibilities of having healthy safe, Aboriginal futures and should indeed our efforts be focused on decolonising the space as a strategy to this end? The continuing colonial cycle revisits the site of originary violence and has a vested interest in retaining its own violent foundation. So as a strategy towards having a life and better still an Aboriginal 
one I am in agreement with Wendy Brown's suggestion that there should be a more direct challenge of imperialism and support for 'indigenous efforts to transform authoritarian, despotic, and corrupt postcolonial regimes'. ${ }^{44}$

The emergency response to the 'Aboriginal crisis' has misrepresented the causes of violence against Aboriginal women and children and reinforced the colonial myth that violence against women is inherent in Aboriginal culture, ${ }^{45}$ rather than considering that the source of violence lies in the invasion and colonisation of Australia and the imprisonment of its Indigenous population. Alternative views on the source of violence in Aboriginal communities have not been given much of an airing in the debate around the Aboriginal 'emergency'. In general, the public knows very little about the complexities of Aboriginal law (beyond the perception of it being acquiescent in violence against women and children). ${ }^{46}$ Aboriginal women are portrayed as victims in need of rescue from violent black males but this view is rarely inverted to reflect on the Australian legal system's failure to protect white women from white male violence. ${ }^{47}$ While the concept of an 'inherent violence' in Aboriginal culture is deployed to explain the rape of small Aboriginal children and the focus is shifted from the social, economic and political environment of those being raped, culture is not deployed to explain the same in the white community. That is a policing matter. The emergency response instead engages the military to resolve sexual assault in Aboriginal communities living on Aboriginal lands in the Northern Territory. On Aboriginal ground, at home, reality is more complex. The violence in Aboriginal communities in my view is more a comment upon the Australian government's management of the colonial project than it is about the culture of the perpetrators of violence. Aboriginal communities across Australia continue to resist the pressure of assimilation, while the public gaze turns away (as it has done before) from the colonial violence of poverty and dispossession of Aboriginal Australia to cultural profiling of the other as barbarian. ${ }^{48}$

The violence of the colonial foundation was a means to an end: the creation of the Australian state. But this endpoint requires constant maintenance and, as I have argued, this maintenance occurs through continuous re-enactments of state violence. Derrida writes that European law prohibits individual violence of the military and its police not simply because the state's laws would be thereby threatened but because individual violence 'threatens the juridical order itself' ${ }^{49}$ In Australia it is the state which is threatened by its own founding violence. ${ }^{50}$

It was just prior to his 2007 election defeat that then-prime minister, John Howard, announced at the Sydney Institute his new interest in reconciliation between Aboriginal and non-Aboriginal Australia, ${ }^{51}$ as he declared: 'We are not a federation of tribes. We are one great tribe, one Australia' and in line with his government's proposed amendments to the Aboriginal Land Rights Act (Cth) 1975 he also announced that 'group rights are, and ought to be, 
subordinate to both the citizenship rights of the individual and the sovereignty of the nation'. ${ }^{52}$ In the space of a united Australia where the many become the one-Australia tribe, what is it that we the Aborigines become? Is this the restaging of Badiou's 'new man', where the creation of a 'new humanity' requires the destruction of the 'old one'?53 In the destruction of the old one Badiou cautions us on the capacity of science to make the new man along with the power of profit to determine its making or unmaking. ${ }^{54}$ The century Badiou reviews, the twentieth, was one in which it is impossible not to see the "unceasing burden of questions of race'. ${ }^{55}$ Along with race there were the questions of contested sovereignties and lawful and unlawful foundation. The impact of these unresolved 'burdens' provides for the continuation of a violent colonial foundation and one that leads to skewed and colonised readings on violence and its origins. This is as well as the negation of the many hundreds of Aboriginal 'tribes' that co-existed in this land we now call Australia at the time of the coming of an 'originary colonial violence'.

IRENE WATSON acknowledges the support of a research fellowship with the University of Sydney Law School, and is an Associate Professor at the University of South Australia. She is the author of a number of articles and books on Aboriginal peoples and law and is currently completing a manuscript, 'Raw Law', for publication.

1. Jacques Derrida, 'Force of Law: The Mystical Foundation of Authority', Cardoza Law Review, vol. 11, 1989, pp. 927, 931, 943, 971-7.

2. Jacques Ranciere, "Who is the Subject of the Rights of Man?', The South Atlantic Quarterly, vol. 103 , no. $2 / 3,2004$, p. 307.

3. Rex Wild and Pat Anderson, Ampe Akelyernemane Meke Mekarle 'Little Children are Sacred': Report of the Northern Territory Board of Inquiry into the Protection of Aboriginal Children from Sexual Abuse, Northern Territory Government, Darwin, 2007, <http://www.nt.gov.au/dcm/inquirysaac/pdf/ bipacsa_final_report.pdf> 30 June 2007>

4. The Howard government on 21 June 2007 announced its intention to use Commonwealth powers to impose a number of emergency measures following the Ampe Akelyernemane Meke Mekarle 'Little Children are Sacred' report.

5. Derrida, p. 949

6. Derrida, pp. 983-5

7. Derrida discusses the 'originary violence' that inheres in the foundation of states, pp. 919-1045.

8. Slavoj Zizek, Violence, Profile Books, London, 2008, p. 99.
9. The 2008 economic crisis has impacted upon proposed uranium and other mining developments in the region and at the time of writing there is an indication of a slowing down of mining developments.

10. Wendy Brown, 'The Most We Can Hope For ... Human Rights and the Politics of Fatalism', The South Atlantic Quarterly, vol. 103, no. 2/3, 2004 , pp. 451-63.

11. Ranciere, pp. 297-310.

12. Gayatri Chakravorty Spivak, A Critique of Postcolonial Reason: Toward a History of the Vanishing Present, Harvard University Press, Cambridge, 1999, p. 284; see also Irene Watson, 'Aboriginal Women's Laws and Lives: How Might We Keep Growing the Law?', Australian Feminist Law Journal, vol. 26, 2007, pp. 95-107, Irene Watson, 'Illusionists and Hunters: Being Aboriginal in this Occupied Space', Australian Feminist Law Journal, vol. 22, 2005, pp. 15-28.

13. For a critical discussion of the history of developments in the area of human rights see Costas Douzinas, The End of Human Rights: Critical 
Legal Thought at the Turn of the Century, Portland, Oxford, 2000

14. For examples of early colonial legislation see as follows: the Aboriginals Protection and Restriction of the Sale of Opium Act (Qld) 1897, s 9, 11, 13;

Aborigines Protection Act (Vic) 1886; Aborigines Act (Vic) 1890; Aborigines Protection Act (WA) 1890 Aborigines Protection Act (NSW) 1909; Northern Territory Aboriginals Act (SA) 1910; Aborigines Act (SA) 1911.

15. See in general the 'history wars' and revisionist. writings on the truth of Australian history, most prominent being the works of Keith

Windschuttle, The Fabrication of Aboriginal History: Volume One Van Diemen's Land 1803-1847, Wakefield Press, Adelaide, 2002.

16. Marcia Langton, 'Trapped in the Aboriginal Reality Show', Griffith Review, vol. 19, 2007, p. 147.

17. The following media report profiles Aboriginal communities as failed states, 'A Failed Indigenous Experiment Ends', Weekend Australian, 23 June 2007 , p. 16. While the intervention was implemented by the Howard government and is now supported by the current Rudd Labor government it was met with resistance, and in Canberra the day before the Rudd government apologised to the stolen generations, 'Thousands to March Against NT Intervention', $A B C$ News (online), 11 February 2008.

18. The recognition of Aboriginality is seen as an illusion in Irene Watson, 'The Power of Muldarbi and the Road to its Demise', Australian Feminist Law Journal, vol. 11, 1998, pp. 28-45, for further discussion on how this illusion is manifested in Australian native title laws see Irene Watson, 'Sovereign Spaces, Caring for Country and the Homeless Position of Aboriginal Peoples', South Atlantic Quarterly, vol. 108, no. 1, 2009, pp. 27-51

19. Aborigines Act (SA) 1934-39, section 1la, provided Aboriginal individuals with an exemption from being identified as an Aborigine from the provisions of the Aborigines Act. For a further discussion on the history of the exemption system in South Australia, see Christobel Mattingley and Ken Hampton (eds), Survival In Our Own Land, Wakefield Press, Adelaide, 1998, p. 49.

20. I say so-called postcolonial because from my lived experiences there is very little which is postcolonial to the Aboriginal experience in Australia.

21. Mal Brough, Aboriginal Land Rights (Northern Territory) Amendment Bill 2006 Second Reading, Commonwealth Parliament of Australia, Canberra, 31 May 2006, <http://parlinfoweb.aph. gov.au/piweb/view_document.aspx? ID =2582653 $\& T A B L E=H A N S A R D R>$.

22. At the same time as the intervention was being talked up the Commonwealth sentencing laws were amended to remove the discretionary power of judges to consider the cultural background of the defendant, Commonwealth Parliamentary Debates, House of Representatives, 28 November 2006, see the amendment to the Crimes Act, 1914 (Cth), s16A, prior to the amendment the court could consider the cultural background of the defendant, in the amended Crimes Act (Cth) 1914, new section $15 \mathrm{AB}$

23. Tanganekald is my mother's people of the Coorong of South Australia; our lands bordered with kin including the Meintangk, as our traditional identities mapped the land.

24. For further discussion on the construction of a non-Aboriginal identity as a result of colonialism see Ward Churchill, Indians Are Us? Culture and Genocide in Native North America, Between the Lines, Ontario, 1994, pp. 232-4.

25. Iris Stevens, Report of the Hindmarsh Island Bridge Royal Commission, State Government Printer, Adelaide, 1995.

26. Slavojk Zizek, How to Read Lacan, Granata Books, London, 2006, p. 29.

27. Zizek, How to Read Lacan, p. 38.

28. The National Emergency Response comprises the following legislation; Northern Territory National Emergency Response Bill 2007 (Cth), Families, Community Services and Indigenous Affairs Amendment Northern Territory National Emergency Response Bill 2007 (Cth), and the Social Security and Other Legislation Amendment (Welfare Reform) Bill 2007 (Cth). This legislation will have an impact upon the following law, the Aboriginal Land Rights Act 1975 (Cth), The Racial Discrimination Act 1975 (Cth), and also the Native Title Act 1993 (Cth), and the Northern Territory Self-Government Act. The following provides a critical Aboriginal response to the intervention, Combined Aboriginal Organisations of the Northern Territory, A Proposed Emergency Response and Development Plan to Protect Aboriginal Children in the Northern Territory: A Preliminary Response to the Australian Governments' Proposal, 2007, among media reports, Patricia Karvelas, 'Crusade to Save Aboriginal Kids Howard Declares "National Emergency" to End Abuse', Australian, 22 June, 2007 p. 1; Michael McKenna, Australian, 22 June 2007, p. 13.

29. Brown, pp. 451-63

30. Brown, p. 454

31. For further discussion see Combined Aboriginal Organisations of the Northern Territory, 
A Proposed Emergency Response and Development Plan to Protect Aboriginal Children in the Northern Territory: A Preliminary Response to the Australian Government's Proposals, 2007; <http://www.apo.org.au/crosspost_linkboard/ items/2007/07/166154-upload-00001.pdf>; Balgo Women's Law Camp, Aboriginal Women Have Answers Themselves, 2007

$<$ http://www.womenforwik.org/cultural_ responses.html>; Jon Altman, Jon, 'The "National Emergency" and Land Rights Reform: Separating Fact from Fiction', <www.anu.edu.au/ caepr/Publications/topical/Altman_Oxfam.pdf> 2007.

32. Families, Community Services and Indigenous Affairs Amendment Bill (Cth) 2007, Schedule 4 will amend the permit provisions under the NT Aboriginal Land Rights Act (Cth) 1975. The federal Labor government has indicated that it would not support this amendment and would retain the current permit system.

33. National Emergency Response Bill, Part 4.

34. National Emergency Response Bill, Part 6, Section 91. These provisions are further explained in the 'Explanatory Memorandum' Pt 6. On 14 July 2006, the Council of Australian Governments (COAG) agreed that no customary law or cultural practice excuses, justifies, authorises, requires, or lessens the seriousness of violence or sexual abuse. All jurisdictions agreed that their laws would reflect this, if necessary by future amendment. COAG also agreed to improve the effectiveness of bail provisions in providing support and protection for victims and witnesses of violence and sexual abuse. The Commonwealth implemented the COAG decision through the Crimes Amendment (Bail and Sentencing) Act 2006, which applies to bail and sentencing discretion in relation to Commonwealth offences. The Bail and Sentencing Act amended the Crimes Act 1914 (Cth) to preclude consideration of customary law or cultural practice from sentencing discretion and bail hearings. The Bail and Sentencing Act also inserted provisions into the Crimes Act requiring the relevant authority to consider the potential impact on victims and witnesses, and specifically the potential impact on victims and witnesses in remote communities, when granting and imposing bail conditions for Commonwealth offences.

35. Irene Watson, Aboriginal Women Law and Colonialism: Safe Places for Women, 2008; at the time of writing this research project is ongoing and has been supported by the Australian Research Council, Discovery Indigenous Researchers Development.
36. The challenge is taken pursuant to the Racial Discrimination Act (Cth) 1975 section 132, arguing that the National Emergency Response Bill by invoking the special measures provision in the Racial Discrimination Act (Cth) 1975 (RDA), enables the exclusion of the operation of Part II of the RDA, so as to avoid a challenge under the RDA. Similarly the Native Title Act (Cth) 1993 invoked the special measures provisions to avoid a challenge under the RDA, however unlike the current challenge the Native Title Act went unchallenged, because at the time it had received popular support for being an 'act of reconciliation' this was even though the Native Title Act validated non-Aboriginal land titles that would have been otherwise claimable lands under the principles in Mabo, for further discussion on Mabo and native title see, Irene Watson, 'Buried Alive', Law and Critique, vol. 13, no. 3, 2002, p. 253.

37. Watson, 'Aboriginal Women's Laws and Lives'

38. Marion Scrymgour, 'Whose National Emergency? Caboolture and Kiribilli? or Milikapti and Mutitjulu?', Charles Perkins Oration, 26 October 2007.

39. See Watson, 'Illusionists and Hunters'.

40. For a further discussion on the construction of Aboriginal culture and the role of the media see Norm Sheehan, "Some Call It Culture": Aboriginal Identity and the Imaginary Moral Centre', Social Alternatives, vol. 20, 2001, p. 29

41. Brown, pp. 459

42. National Emergency Response Bill, Part 4.

43. Brown, pp. 459-60.

44. Brown, p. 460.

45. See Watson, 'Aboriginal Women's Laws and Lives' and for a different position see Zizek, How to Read Lacan, p. 38.

46. Catherine Wohlan, Aboriginal Women's Interests in Customary Law Recognition, Background Paper no. 11, Law Reform Commission of Western Australia, 2005, pp. 1-10, discusses the complex interaction between Aboriginal and AngloAustralian laws and the failure of law to comprehend the high levels of violence in Aboriginal communities. Wohlan contextualises the problem as not being sourced in Aboriginal law, instead suggesting Aboriginal law 'has the potential to be a useful tool in addressing community justice', p. 1 .

47. In a recent South Australian court decision His Honour Judge Gordon Barrett referred to 'culture sickness' in relation to the impact of Aboriginal people disconnected from country as an explanation for the rape of a woman. See 'Rapist's 
"Cultural Sickness"', Advertiser, South Australia, 10 June 2006, p. 21.

48. See further comment by Slavoj Zizek, New York Times, 11 October 2007.

49. Derrida writes, 'militarism is a modern concept that supposes the exploitation of compulsory military service, is the forced use of force, the compelling to use force or violence in the service of the state and its legal ends', Derrida,

pp. 1001-7. See also Rosemary Hunter, 'Law's

(Masculine) Violence: Reshaping Jurisprudence', Law and Critique, vol. 17, 2006, p. 30 in reference to Derrida's argument on how it is Western law prohibits individual violence not because it poses a threat to this or that law (or person), but because it threatens the juridical order. In other words, law seeks to monopolise violence not in order to protect legal subjects, but to protect itself from challenge-in particular, from new acts of revolutionary violence, which might found a new legal order.

50. Derrida, p. 989

51. The Howard position had previously been against reconciliation in terms of a 'rights' discourse, preferring the pragmatic approach of 'practical reconciliation'.

52. Dennis Shanahan, 'Howard's New Reconciliation', Australian, 12 October 2007, pp. 1 and 4

53. Alain Badiou, The Century, Polity Press,

Cambridge, 2007, p. 8.

54. Badiou, p. 9.

55. Badiou, pp. 14-15 